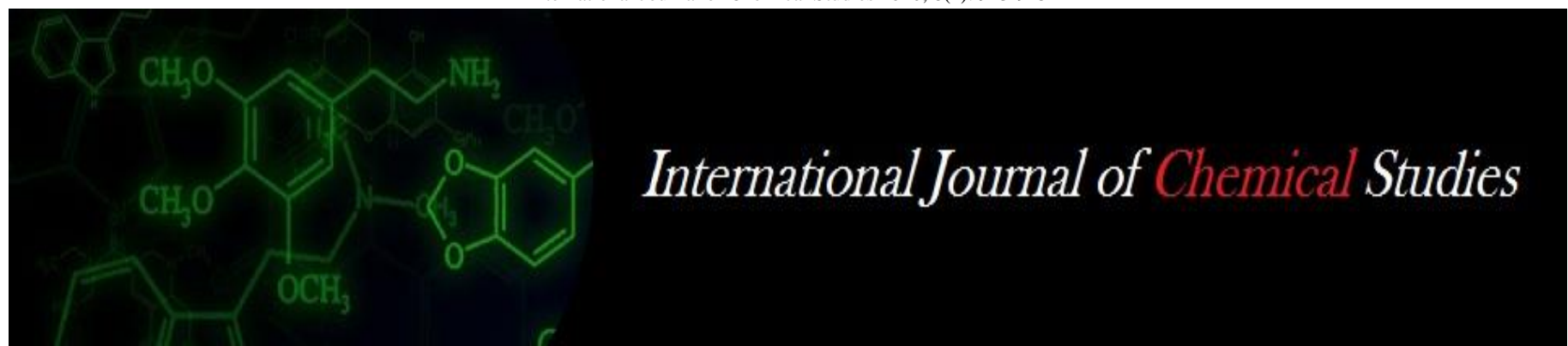

P-ISSN: 2349-8528

E-ISSN: 2321-4902

www.chemijournal.com

IJCS 2020; 8(2): 913-915

(C) 2020 IJCS

Received: 16-01-2020

Accepted: 18-02-2020

Meera Choudhary

Department of Plant Pathology,

SKN College of Agriculture

(SKNAU), Jobner, Jaipur,

Rajasthan, India

RP Ghasolia

Department of Plant Pathology,

SKN College of Agriculture

(SKNAU), Jobner, Jaipur,

Rajasthan, India

Tejpal Bajaya

Department of Plant Pathology,

SKN College of Agriculture

(SKNAU), Jobner, Jaipur,

Rajasthan, India

Manisha Shivran

Department of Plant Pathology,

SKN College of Agriculture

(SKNAU), Jobner, Jaipur,

Rajasthan, India

Corresponding Author:

Meera Choudhary

Department of Plant Pathology,

SKN College of Agriculture

(SKNAU), Jobner, Jaipur,

Rajasthan, India

\section{Efficacy of natural products and fungicides against powdery mildew of ber}

\author{
Meera Choudhary, RP Ghasolia, Tejpal Bajaya and Manisha Shivran
}

DOI: $\underline{\text { https://doi.org/10.22271/chemi.2020.v8.i2n.8884 }}$

\begin{abstract}
Indian jujube or ber (Ziziphus mauritiana Lamk.) is one of the most common fruit, indigenous to an area joined from India to China. Powdery mildew of ber incited by Oidium erysiphoides f. sp. ziziphi, Yan and Wang is the most important disease that causes maximum reduction in yield and quality of ber fruits. Exclusive reliance on fungicides for the control of disease of various crops resulted in residue and environmental hazards. Therefore, in recent years, efforts are being diverted to employ higher plants, natural products and their derivatives as a tool for integrated disease management because they do not cause bio-accumulation, bio-magnification and environmental pollution. In present investigation, six natural products (buffalo milk, cow milk, garlic extract, neem oil, mustard oil, butter milk/chhach) were evaluated for their efficacy against powdery mildew of ber. The jujube or ber is an ancient fruit of India and China. It was one of the prominent fruits on which the sages in ancient India lived during the Vedic age and lived even today. Ber is a hardy crop which grown in arid conditions of Rajasthan, characterized by sandy soils, scanty rainfall $(400-600 \mathrm{~mm})$, thermal oscillations $\left(5-35{ }^{\circ} \mathrm{C}\right)$ and low relative humidity. Therefore, the area of cultivation is increasing in this zone (arid and semi arid) and is expected that in near future ber will be a leading fruit crop of arid zone. The cultivation of ber requires the least input and care. In natural products maximum intensity over control was observed with garlic extract followed by neem oil, mustard oil, cow milk, buffalo milk and least effective was butter milk. Among the five systemic and non systemic fungicides (difenoconazole, dinocap, hexaconazole, tridemorph and wettable sulphur) tested against powdery mildew of ber, the maximum reduction in disease intensity over control was observed in dinocap $(0.1 \%)$ with lowest per cent disease intensity $(9.60)$ followed by hexaconazole, wettable sulphur, tridemorph and least effective was difenoconazole.
\end{abstract}

Keywords: Ber, Ziziphus mauritiana, powdery mildew, natural products and fungicides

\section{Introduction}

Indian jujube or ber (Ziziphus mauritiana Lamk.) is one of the most common fruit, indigenous to an area joined from India to China. The genus Ziziphus has been derived from 'Zizaif' which is the Arabic name of the fruit (Bailey, 1947) ${ }^{[2]}$. The ber belongs to the family Rhamnaceae which has about 50 genera and more than 600 species (Pareek, 1983) ${ }^{[11]}$. In India, ber is being cultivated on an area of about 4,845 hectares with production of 66,296 metric tonnes and productivity of 13.68 metric tonnes (Anonymous, 2014) ${ }^{[1]}$. Ber is a hardy crop which grown in arid conditions of Rajasthan, characterized by sandy soils, scanty rainfall (400-600mm), thermal oscillations $\left(5-35{ }^{\circ} \mathrm{C}\right)$ and low relative humidity. Powdery mildew of ber incited by Oidium erysiphoides f. sp. ziziphi, Yan and Wang is the most important disease that causes maximum reduction in yield and quality of ber fruits (Ziziphus mauritiana Lamk.). Due to powdery mildew recorded per cent disease index 17-71 at fruiting stage of ber (Oidium sp.) in Bijapur, India (Jamadar et al., 2009) ${ }^{[9]}$. Ber is attacked by many of the diseases caused by fungi and other pathogenic agents. Among these, powdery mildew is one of the most important, wide spread and easily recognized diseases. Among these, powdery mildew caused by Oidium erysiphoides f. sp. ziziphi, Yan and Wang (Microsphaera alphitoides f. sp. ziziphi Griffon and Maublanc) is a major disease of jujube in India (Jamadar et al. 2009) ${ }^{[9]}$. Due to powdery mildew (Oidium sp.) per cent disease index recorded 17-71 at fruiting stage of ber in Bijapur, India (Jamadar and Desai, 1996) ${ }^{[10]}$. 


\section{Material and Methods}

Disease Control through natural products

In lieu of organic produce for the consumers, the following natural products were used to test their efficacy against powdery mildew of ber on ten years old susceptible variety Gola. The concentration of natural products was decided as per available information in literature.

The concentration of natural products was decided as per available information in literature.

\begin{tabular}{|c|c|}
\hline Natural products & Dose (\%) \\
\hline Buffalo milk & 10 \\
\hline Butter milk (Chhach) & 10 \\
\hline Cow's milk & 10 \\
\hline Garlic extract & 10 \\
\hline Mustard oil & 0.5 \\
\hline Neem oil & 0.5 \\
\hline
\end{tabular}

Neem oil, mustard oil, cow milk, buffalo milk and butter milk (Chhach) were applied as per required concentration while garlic extract was prepared as follows. Hundred gram garlic cloves were taken with $100 \mathrm{ml}$ of water and then grinded in juicer mixer grinder and filtered through double layered muslin cloth. This was considered as 100 per cent concentration and sprayed (10\%) on ber trees (Sindhan et al., 1999) ${ }^{[13]}$.

The experiment was conducted at Asalpur Farm, Jobner in RBD with four replications. Two sprays of each natural product was applied, first spray at the time of disease initiation and second at fifteen days interval. Observation for disease intensity was recorded at fifteen days after second spray. Per cent disease control over check was calculated as follows.

$\%$ disease intensity in control - \% disease intensity in treatment Per cent disease control = ---------------- x 100 $\%$ disease intensity in contro

\section{Disease control through fungicides}

The following five systemic and non-systemic fungicides were evaluated by applying as foliar spray in RBD with four replications on ten year old susceptible variety Gola. Two sprays of each fungicide were applied, first spray at the time of disease initiation and next at fifteen days interval. Observation and calculation of per cent disease intensity and per cent disease control were as per followings

Observation and calculation of per cent disease intensity and per cent disease control were as per followings

\begin{tabular}{|c|c|c|}
\hline Common Name of fungicide & Trade Name & Dose (\%) \\
\hline Wettable sulphur & Sulfex 80\% WP & 0.2 \\
\hline Dinocap & Karathane 48\% EC & 0.1 \\
\hline Tridemorph & Calixin $80 \%$ EC & 0.1 \\
\hline Hexaconazole & Contaf 5\% EC & 0.1 \\
\hline Difenoconazole & Score 25\%EC & 0.1 \\
\hline
\end{tabular}

Table 1: Efficacy of natural products against powdery mildew (Oidium erysiphoides f. sp. ziziphi) of ber

\begin{tabular}{|c|c|c|c|}
\hline Natural products & Concentration (\%) & Per cent disease intensity* & Per cent disease control \\
\hline Buffalo milk & 10 & 29.91 & 16.45 \\
\hline Cow milk & & $(33.21)$ & 18.43 \\
\hline Garlic extract & 10 & 29.2 & 44.69 \\
\hline & 10 & $(32.58)$ & 39.94 \\
\hline Neem oil & 0.5 & 19.8 & 29.89 \\
\hline Mustard oil & & $26.57)$ & \\
\hline & 0.5 & $(27.97)$ & 9.33 \\
\hline Butter milk (Chhach) & 10 & 25.1 & - \\
\hline & & $(30.00)$ & - \\
\hline Check & - & 32.46 & - \\
\hline (Without any spray) & - & $(34.45)$ & - \\
\hline SEm \pm & - & 35.8 & $(36.87)$ \\
\hline CD $(p=0.05)$ & - & 0.28 & \\
\hline
\end{tabular}

*Average of four replications

Figures given in parentheses are angular transformed values

Table 2: Efficacy of fungicides against powdery mildew (Oidium erysiphoides f. sp. ziziphi) of ber

\begin{tabular}{|c|c|c|c|}
\hline Fungicides & Concentration (\%) & Per cent disease intensity* & Per cent disease control \\
\hline Difenoconazole & 0.1 & 16.26 & 54.58 \\
\hline Dinocap & & $(23.58)$ & 73.18 \\
\hline & 0.1 & 9.6 & 66.06 \\
\hline Hexaconazole & 0.1 & $(17.95)$ & 58.67 \\
\hline Tridemorph & 0.1 & 12.15 & 59.78 \\
\hline Wettable sulphur & 0.25 & $(20.27)$ & \\
\hline Check & & 14.8 & - \\
\hline (Without any spray) & - & $(22.79)$ & - \\
\hline SEm \pm & - & $(22.38)$ & - \\
\hline CD $(\mathrm{p}=0.05 \%)$ & - & 35.8 & $-36.87)$ \\
\hline
\end{tabular}

*Average of four replications

Figures given in parentheses are angular transformed values 


\section{Result and Discussion}

Disease control through natural products

It is evident from the Table 1 that out of six natural products (buffalo milk, cow milk, butter milk, garlic extract, mustard oil and neem oil) the maximum reduction in disease intensity was observed with garlic extract $(44.69 \%)$ followed by neem oil (39.94\%), mustard oil (29.89), cow milk (18.43\%) and buffalo milk (16.45\%) and butter milk $(9.33 \%)$ was found least effective in reducing disease intesity over check. However buffalo milk and cow milk were found at par with each other. Bettiol et al. (2008) ${ }^{[3]}$ have also been tested effectiveness of whey against powdery mildew (Podosphaera xanthii) of cucumber and zucchini squash in greenhouse. Plants were sprayed once or twice a week with whey at concentrations of $5,10,15,20,25$, and 30 per cent in water. Disease progress was more slowly in plants treated with 2530 per cent whey than lower concentration was used. Surwase et al. (2009) ${ }^{[14]}$ also reported that NSKE was found most effective and economic against Erysiphe polygoni causing pea powdery mildew and gave better seed yield.

\section{Disease control through fungicides}

Out of five (difenaconozole, dinocap, hexaconazole, tridemorph and wettable sulphur) systemic and non-systemic fungicides tested (Table 2), the maximum reduction in disease intensity was observed with dinocap $(73.18 \%)$ followed by hexaconazole (66.06\%), wettable sulphur (59.78\%) and tridemorph $(58.67 \%)$ and difenoconazole $(54.58 \%)$ was found least effective in reducing disease intesity over check. However wettable sulphur and tridemorph were found at par with each other in controlling each other. The results are in agreement with several workers (Das, $1994^{[5]}$, Reddy et al., $1996^{[12]}$, Dang et al., $1997^{[4]}$, Jamadar and Desai, $1998^{[8]}$ and Jamadar et al., 2009) who reported dinocap as most effective in reducing powdery mildew. Similar result have also been observed excellent with dinocap in controlling powdery milew of ber (Gupta et al. 1977) ${ }^{[7]}$. It have also been obtained good control of ber powdery mildew with various fungicides including dinocap and sulfex (Das et al. 1994, Desai 1998 and Thind and Kaur 2006) ${ }^{[5,6,15]}$.

\section{Conclusion}

It can be concluded that in natural products the maximum reduction in disease intensity was observed in garlic extract and in fungicides maximum reduction in disease intensity was observed in dinocap.

\section{Acknowledgement}

The authors are thankful to the Head, Department of Plant Pathology and Dean, SKN College of Agriculture (SKNAU), Jobner for providing all required facility to completed this task.

\section{References}

1. Anonymous. Indian Horticulture Database-2014, National Horticulture Board, Gurgaon, 2014.

2. Baily LH. The Standard Cyclopoedia of Horticulture. Macmilan and Co., New Yark, 1947, 3547-8.

3. Bettiol W, Silva HAS, Reis RC. Effectiveness of whey against zucchini squash and cucumber powdery mildew. Scienta Hort. 2008; 117:82-84.

4. Dang, JK, Sangwan MS, Mehta, Naresh, Kaushik CD and Mishra BP. Flusilazole (Punch)-a potential fungicide for control of different powdery mildews. Annals Agri Bio Res. 1997; 2(1):15-19.
5. Das ND, Rao MSM, Sankar BRM. Efficacy of two new fungicides for the control of powdery mildew of ber and compatibility test of recommended fungicides with insecticides. Annals Pl Prot Sci. 1994; 2(2):76-78.

6. Desai SA. A note on the spray schedule for the control of powdery mildew of ber in Karnataka. Karnataka J Agri. Sci. 1998; 1(1):242-243.

7. Gupta JH, Ramnath, Srivastav VP. Chemical control of powdery mildew of ber (Ziziphus mauritiana Lamk.). Progressive Hort. 1977; 9(1):81-83.

8. Jamadar MM, Desai SA. Chemical control of powdery mildew of ber. J Agri Sci. 1998; 11(2):415-418.

9. Jamadar MM, Balikai RA, Sataraddi AR. Status of diseases on ber (Ziziphus mauritiana Lamk.) in India and their management options. Acta Hort. 2009; 840:383390.

10. Jamadar, MM and Desai, SA. 1996. Varietal screening of ber against powdery mildew. Karnataka J Agri Sci. 1983; 9(3):545-546.

11. Pareek OP. The Jujube. Indian Council of Agricultural Research, New Delhi, 1983, 7.

12. Reddy MM, Reddy GS, Madhusudan T. Efficacy of fungicides against powdery mildew (Oidium erysiphoides f. sp. ziziphi) of ber (Ziziphus mauritiana Lamk.). Indian J P1 Prot. 1996; 24:64-68.

13. Sindhan GS, Hooda I, Parashar RD. Evaluation of plant extract for the control of powdery mildew of pea. J Myco Pl Pathol. 1999; 29(2):257-258.

14. Surwase AG, Badgire DR, Suryawanshi AP. Management of pea powdery mildew by fungicides, botanicals and bioagents. Annals Plant Prot Sci. 2009; 17:384-388.

15. Thind, SK, Kaur N. Management of ber powdery with fungicides. Indian J Hort. 2006; 63(3):267-269. 